The politics of guarding the Treaties: Commission scrutiny of rule of law compliance

\title{
Carlos Closa
}

\section{Abstract}

Commission's expectations on eventual compliance explain its different behaviour when dealing with Rule of Law (RoL) crises in Hungary and Poland. Whilst the Commission activated the first stage of the procedure of article 7 against Poland in December 2017, it resisted to launch the same procedure against the Hungarian government despite mounting criticism and demands from both academics and EU institutions. The Commission considers that compliance depends, on last instance, on the cooperation of domestic authorities. Accordingly, it prefers to engage with them in dialogue and persuasion rather than activating enforcement mechanisms. If engagement strategies fail to obtain compliance, the Commission anticipates the consequence of activating article 7 enforcement: whether it can rely or not on Council support and the effects of not having it and it also anticipates negative consequences such as the future attitude of the affected member state vis-á-vis the EU.

\section{Key words}

Compliance with EU law, enforcement of EU law, EU Commission, Rule of law, institutional behaviour.

\section{Introduction}

On 20 December 2017, the Commission activated the preventive stage of Article 7 for the first time. Illiberal changes in Hungary (since 2011) and Poland (since 2015) had caused alarm, prompting calls for the activation of the mechanism from EU institutions (EP; 2017a and 2017b) and scholars alike (Editors CMLR; 2016:601; Pech and Scheppele; 
2017a). While the Commission refrained from acting against Hungary, it did against the Polish government. The different outcomes in these two cases raises a crucial question: why has the Commission activated Article 7 against Poland? What explains the different treatment in relation to Hungary?

Scholars have speculated with possible explanations for the Commission's actions but they have not tested them systematically. This paper proposes a theoretically informed explanation, combining the Commission's preference for compliance through engagement with its anticipation of the consequences of its own decisions. Firstly, when deciding how to enforce European Union (EU) law, the Commission considers the possibility of obtaining effective compliance without coercion. Given the EU's reliance on the national authorities for compliance, the Commission always favours instruments that preserve its engagement with them. Failing to achieve the engagement of the offending government, Commission decisions' on activating enforcement actions depend on the anticipation of their effects. On the one hand, the Commission anticipates the positions within the Council and the European Council in relation to procedures in article 7. Estimating that no Council majority or, even less so, European Council unanimity existed in support of its proposals, the Commission anticipated hypothetical negative effects of failing to obtain backing, such as reinforcing domestic offenders and/or erosion of its authority. On the other hand, the Commission also anticipates the possible negative domestic effects of a decision against an offending government: a sanctioning decision can backfire by provoking a 'rally-round-the-flag' effect. Whilst the later effect does not seem to play an important explanatory role, the combination of the preference for enforcement by engagement and the anticipation of effects because of lack of Council support hypotheses provides the most robust 
explanation for Commission action. I first describe EU Commission actions in relation to the protection of the Rule of Law in its Member States and, the, I present the theoretical discussion of the various hypotheses. . I present next the evidence drawn from interviews with Commission officials and former Commissioners that support each of these hypotheses and then I discuss the theoretical implications of these findings. Finally, the conclusion restates the paper's main theories.

2. Commission performance on the protection of the rule of law

The governments and parliamentary majorities of Hungary (since 2011) and Poland (since late 2015) have carried through legal changes whose cumulative effect is the reinforcement of the powers of the executive and the concomitant erosion of the principle of separation of powers. The Hungarian government has used its constitutional majority to reform the Constitution whilst the Polish government, lacking a similar majority, has implemented changes perceived as unconstitutional. These transformations have prompted concerns about the breach of rule of law value mentioned in article 2 of TEU. Puzzling, despite widespread perception of the similar systemic effect in both countries, Commission's actions have differed.

Thus, the Commission launched three successful infringement procedures in 2012 with RoL significance against Hungary. The Cout of Justice of the EU (CJEU) upheld the Commission's views in the three (concerning the independence of the data protection authority and the central bank, and changes to the compulsory retirement age for judges). notification In several other cases (regarding the concentration of the operational management of the courts, human resources, budget and the allocation of 
cases into the hands of the president of a new National Judicial Office), the Commission only reached the stage of a formal letter of. In 2017, the Commission opened two additional infringement procedures concerning the Hungarian 'anti-CEU' legislation and foreign funding of Non Governmental Organizations (NGOs). The Commission also warned that it remained resolved to use all available instruments while simultaneously calling for a broader political dialogue involving the Hungarian authorities. However, the Commission has so far failed to activate its own RoL Framework against Hungary, despite explicit European Parliament (EP) requests in 2015 (EP; 2015a and 2015b). Several commentators (e.g. Kochenov; 2016) have condemned the Commission's failure to activate Article 7 against Hungary.

In contrast, the Commission has taken much firmer action against the Polish government. In January 2016 it activated the RoL Framework barely three months after the formation of a Law and Justice (PiS) government. The Commission escalated the various stages of the RoL Framework: having received no response from the Polish authorities to its January Opinion, it published a Recommendation on July 2016. The Polish authorities did not address the issues contained in the Recommendation and adopted a confrontational stance. The Commission issued another Complementary Recommendation that acknowledged that important issues remained unsolved while further concerns had emerged in the meantime. In July 2017, following the approval of four Polish laws reforming the judicial system, the Commission launched a first infringement procedure and issued a third Recommendation within the Framework which explicitly threatened to activate Article 7. Finally, on 20 December 2017, the Commission approved a fourth Recommendation and initiated the first stage of the article 7 procedure. 
The huge scholarly criticism (Kelemen; 2017; Kochenov; 2016; Kochenov and Pech; 2016; Pech and Scheppele; 2017a\&b; Scheppele; 2016) has targeted the limited enforcement actions (limited to infringement actions); the lack of Commission readiness to activate article 7 against Hungary and the slowness in Commission activation of the article against Poland. The Commission has officially justified its limited action appealing to the alternative enforcement via infringement action and the compliance obtained once the CJEU ruled on them and has officially argued that dialogue should happen before the Framework could evolve into the activation of article 7. The following section offers alternative theoretical explanations for Commission limited action and the activation of article 7 .

\section{Explaining institutional action and inaction}

The predominant explanation for institutional inaction (Kelemen, 2016 Seldelmeier, 2014 and 2017; Sargentino \& Dimitrov; 2016) singles out EP group membership. Thus, members of the same EP group tolerate RoL backsliding if the offenders belong to the same group but will act against it if they belong to a different EP group (Van Hüllen and Börzel; 2013; Sedelmeier; 2014 \& 2017; Kelemen; 2016). More generally, party politics would also explain the difference in the way the EU treats Hungary and Poland (Zalan; 2015). Sedelmeier (2017) has convincingly tested the partisanship hypothesis using a sophisticated Qualitative Case Analysis for the EP where party politics and voting alignments are easily traceable in votes on resolutions condemning the specific policies of these governments. However, the effectiveness of the partisanship hypothesis for explaining Commission RoL actions remains untested. 
The Commission's independent status implies that acting on the bases of political affiliation can be perceived as a violation of its treaty obligations (Wilms; 2017: 66). We can thus assume prima facie that the Commission acts autonomously from national instructions and even ideological preferences. Moreover, Kassim et al (2013) have not found any evidence that ideology or more specifically party affiliation plays any role at all in explaining the Commission's activity and these findings confirm previous research (Wonka; 2008). However, alternative evidence (Wille; 2013: 88-89) challenges this conclusion and substantiates the thesis that ideology (partisanship) could explain the Commission's actions to a certain extent, to the point that Egeberg (2014) concludes that the European Commission today is [...] probably more of a political body than a typical technocracy. Moreover, the Spitzenkandidaten process has further increased the Commission's politicisation (Peterson; 2017). Translating the argument to RoL protection, Kelemen (2016: 226) argued that the Commission's explicit refusal to activate its Framework against Hungary following explicit requests from the EP in 2015 occurred for party political reasons: the European People's Party (EPP)-dominated Juncker Commission refused to activate the Framework because only left-leaning parties backed the EP Resolution, while the EPP opposed it. Given conflicting evidence, I will test the partisanship thesis by constructing the following hypothesis.

H1. Partisanship explains Commission behaviour. If the offending government belongs to the same party as the one dominating the Commission, no activation of article 7 should be expected. 
An alternative explanation for Commission action states that it anticipates the effects of its decisions. If the Commission anticipates undesired consequences from its enforcement actions, it may refrain from acting. This calculation involves three different effects. First, the Commission might act based on the probability that decision-making bodies, mainly the Council (and, by extension, the European Council) will uphold its initiative. Then, the Commission's calculation could also consider whether, even if it obtains Council support, the effects of the decision could either backfire, second, and/or not achieve actual compliance, third.

In relation to the anticipation of Council's support, Vitorino (2012) observed in general terms that the Commission is now forced to pay increasing heed to the guidelines and suggestions put forward by the European Council and Parliament and this intensifies in cases of co-legislation. However, Nugent and Rhinard (2016) found mixed evidence of the thesis that the Commission adopts a much more cautious approach because of the increase in intergovernmentalism during the crisis. Whilst these considerations apply generally to all EU decision-making, Article 7 constructs an even more pronounced decisional imbalance between the initiator (i.e. Commission) and the decision-maker (i.e. Council/European Council). The preventive procedure requires a 4/5ths qualified majority of the Council plus EP consent, whilst the corrective stage requires the European Council to act by unanimity. In a second step within the corrective stage, the Council may decide to adopt sanctions by qualified majority (although the $4 / 5$ ths requirement of the preventive stage disappears.

These high decisional thresholds create a genuine risk that the Council could overrule the Commission, in particular if unanimity is required (Kelemen; 2016: 230; Scheppele, 2016). The political damage could be considerable since a Council refusal 
would amount to an endorsement of the illiberal course of the offending government (Wilms; 2017: 68; Editors CMLR 2016). Commission action would thus be expected if there were evidence that a significant and sufficient number of governments would be prepared to support its initiative. Alternatively, the Commission may refrain from action if it believes that the governments will not support its initiatives (Kochenov and Pech; 2016: 1066). As Pech and Scheppele (2017b) have noted, Commission hesitation can create a kind of circularity: why would any national government signal its intent to support the Commission when there is no certainty the Commission may trigger Article $7 ?$.

Authors have rightly noted the reluctance of national governments to act as controllers of each other's behaviour. Thus, Wilms (2017: 65-66) reports that Member States have only rarely used the procedure for national governments to bring to justice a non-compliant Member State for violation of an obligation under the Treaties (Article 259 Treaty on Functioning of the EU, TFEU). In relation to Article 7, expecting states to initiate such a procedure amounts to asking turkeys to vote for Thanksgiving (Grabbe; 2014). I derive the following hypothesis to test against empirical evidence.

\section{H.2.1 The Commission anticipates support in the Council/European Council as a prerequisite for the activation of Article 7.}

The Commission may also decide calculating that the decision may either backfire or may not achieve compliance. Backfiring means that sanctions may increase domestic support for the offending government (the rally-round-the-flag effect). The literature on sanctions has identified that this rally-round-the-flag effect occurs whenever a threat of 
sanctions arouses a nationalist response within the target government or population, undermining the effectiveness of the threat (Galtung, 1967). Research has shown that under certain conditions, sanctions trigger a rally-round-the-flag effect and support for authoritarian leaders (Lindsay, 1986; Grauvogel and von Soest; 2014), although as states become more politically open, the costs of leaders resisting sanctions increase (Allen; 2008). Pervasive nationalism can further exacerbate the rally-round-the-flag effect since it inclines states and societies to endure considerable punishment rather than abandon what are viewed as the national interests (Pape; 1997).

Observers have warned that rally-round-the-flag effects could emerge if the EU activates Article 7 (Schlipphak and Treib; 2016; Editors CMLR; 2016: 602) increasing, as a consequence, the support for those domestic actors that EU intervention is supposed to weaken (Schlipphak and Treib; 2016). Commission-led decisions can have a galvanising effect within the 'indicted' state and as a corollary, further alienate this Member State's government and population from the European Union and its institutions (Bieber and Maiani; 2014; Wilms; 2017: 68).

Opinions that the 1999 sanctions against Austria produced these kinds of unintended and undesired consequences (Ahtisaari et al; 2000; Merlingen et al; 2001; Oreja; 2011; Wilms; 2017: 70) adds credibility to this thesis relies that. Schlipphak and Treib; 2016) observe a similar effect in Hungary in relation to infringement procedures launched by the Commission. Despite the appeal of this thesis, the literature on the rallyround-the-flag effect has assessed whether the expectations of enforcers on the effect's emergence actually conditions their behaviour. Hypothetically, the fear that activating even soft sanctions against offending Member States could trigger a domestic reaction 
against the EU could enter into the Commission's calculations, determining whether to initiate sanctions.

H2.2 The anticipation of possible unintended and unwanted effects in the form of increasing domestic support for rule of law offenders would affect the Commission's decisions to activate article 7.

Finally, the literature on compliance with EU norms (Börzel; 2001; Tallberg; 2002; Börzel et al; 2010; Conant; 2012; Falkner; 2013) has discussed whether Member States comply with these and has established a typology of mechanisms for achieving compliance, distinguishing voluntary and non-voluntary compliance. However, this literature has not looked into how expectations about compliance shape the behaviour of the actors to which states delegate power to secure compliance. Even if enforcement is possible, lawyers coincide in that Member States' compliance with EU law is ultimately voluntary and the EU is, unlike many federal states, not even theoretically empowered to use coercion to enforce EU law against a recalcitrant Member State (Roland and Maiani; 2014: 1060-1). The late arrival of sanctions to the EU system (the Maastricht Treaty introduced 'monetary sanctions' where the CJEU found a Member State to be in breach of compliance with a previous judgment) demonstrates the rooted belief in voluntary compliance. Commission performance in other policy areas illustrates its shyness to apply coercive enforcement mechanisms. Accordingly, after 2003, the Commission refrained from triggering the sanctioning mechanisms foreseen in the Excessive Deficit Procedure under Article 126 TFEU, while simultaneously the number of Member States 
found to be in breach of the excessive deficit prohibition had risen to 17 in 2013 (Roland and Maiani; 2014: 1066).

The Commission almost always attempts to resolve breaches of compliance through a structured dialogue with the Member State in question (Batory: 2016: 688) and uses enforcement mechanisms very carefully. Blauberger andKelemen (2017), who support the intensification of the use of infringement procedures for rule of law related offences, record that the Commission favours a selective application of the infringement procedure. This cautious or selective approach derives from Commission's fear of damaging its own credibility: If a Member State defies the Commission or ignores a ruling by the CJEU, it undermines the community of law that underpins European integration (Grabbe; 2014: 46). As a result, Commission officials, aware of the fragility of the system, try to engage with the Member States and find solutions rather than seeking confrontation. The Commission prefers persuasion strategies (Checkel 2001; Tallberg 2002; Hartlapp 2007; Börzel et al 2010) before Court action. Even when the Commission activates infringement procedures, it engages with the offending government and exercises its discretionary management of the various stages of the procedure (Mendrinou 1996, p. 12). The successive steps of the elongated infringement procedure seek to achieve 'quiet accommodation with the member state', with the Commission consistently emphasizing 'the need to preserve the cooperative model of decisionmaking [...][invoking] [m]utual trust and confidence' (Rawlings; 2000). Sedelmeier (2014: 113) observed that the Commission's implementation strategy relies on a combination of formal and informal, and coercive and problem-solving instruments, bundled together to maximize leverage, while Bátory (2016: 688) argues that the nature of the mix of tools varies from case to case, and from policy area to policy area, but legal formalism (... 
conformity with the letter of the law), and a preference for consensual tools over coercive action are common features of the Commission's strategy.. Legal formalism also means that the Commission prefers to base its actions on explicit legal bases and this leads to reliance on breaches of specific treaty provisions instead of the more undefined and legally undetermined Article 2. The Commission therefore prefers infringement procedures as the main instrument to obtain compliance since they combine clear legal competence to act with a flexible approach and combination of engagement and ultimate enforcement. The more punitive enforcement mechanisms (such as activation of Article 7) are perceived as the last resource since it alienates national governments which are ultimately the agents who must implement EU law and decisions nationally.

This compliance dilemma informs Commission enforcement strategy, which makes negotiation the prime means of promoting compliance (Bieber and Maiani; 2014). The same applies to enforcement of Article 7. Alternative mechanisms that avoid confrontation and enhance engagement with domestic authorities are preferred to sanctions if only because they guarantee compliance: ceasing illegal behaviour is a much clearer expression of promoting respect for the RoL than punishment (Wilms; 2017). This of course creates perverse effects, since creative and symbolic compliance can be successfully employed because it enables the Commission to disengage from conflicts it judges too costly and yet maintain credibility. The Commission may go along with and even applaud the outcome because it shares an interest with the offending member state in avoiding a compliance crisis, even though the intended change is not achieved on the ground (Bátory; 2016). This discussion informs the following hypothesis 
H2.3 Anticipating compliance obstacles, the Commission prefers actionswhich secure the offenders' engagement rather than activating article 7.

4. Research design, methods and data

This paper examines the EU Commission actions regarding the governments of Fidesz in Hungary (2010-2017) and Law and Justice (PiS) in Poland (2015-2017), where it scrutinised these governments' breaches of the RoL. The Venice Commission of the Council of Europe and the EP itself documented clear violations of the RoL in both cases. The Commission has sought enforcement through four infringement procedures against Hungary but it has only activated Article 7 procedure against Poland (after previous activation of the Framework on the Rule of Law). The Commission also engaged in a number of dialogues and informal exchanges with both governments. The dependent variable adopts two dichotomous values (i.e. activation/no activation of article 7).

To validate the hypotheses drawn from theory above, I have established observable implications for each. Observable implications are the facts and/or data to be found if a hypothesis were borne out. To confirm a hypothesis, the empirical evidence must match the expectations of its observable implications.

Table 1 above here

Empirical evidence originates from two sources. First, Commission documents, in particular speeches, declarations and press releases, provide information on 
Commission actions. I have coded 43 documents directly related to breaches of the RoL that the Commission has issued between 2012 and 2017. These provide justification for its actions and the codification assigned codes deduced from the various hypotheses.

Secondly, I have conducted nine interviews with key decision makers. Causal processes can be identified in some very specific instances of decision-making at the elite level, where a limited set of actors are involved in deliberations, decisions and actions regarding the political outcome. Policymaking on the RoL within the Commission involves such a limited group.

Elite interviewing requires that the sample comprises the most important political actor who participated in the political events under study. This in turn requires reducing randomness and applying positional sampling: the researcher uses positional criteria to identify desirable respondents (the analysis specifies a set of positions or occupations) of the key elites at the focus of the study (Tansey; 2017). All the people interviewed are current or former officials from the Commission's Directorate General (DG) on Justice and Consumers (previously, DG Justice, Freedom and Security and even before, DG Justice and Home Affairs), and higher Commission ranks. Given its small size, these comprise the group of Commission members directly involved with the RoL. The people interviewed include four former Commissioners (including a former Vice-President of the Commission and a former member of the 2000 Wise Men Group), two DGs and a Head of Unit, plus two members from the Commissioners' cabinets. ${ }^{i}$ I used semistructured interviews that I held in 2017 between Brussels, Florence, Luxembourg, Madrid and Miami. I codified the transcribed interview texts, assigning hypothesisrelated codes. 
Interviews, of course, have limitations as sources of evidence since interviewees may conceal motivations, preferences and interests. But if the aggregate of interviewees systematically conveys the same motivations, preferences and interests, then the assumption of certainty cannot simply be rejected unless dis-conforming or refuting evidence is provided. I have triangulate information against existing sources such as newspapers and online newsletters in order to confirm or eventually refute the internal validity of the evidence.

5. Explaining Commission action/inaction

5.1. Does partisanship explain Commission actions?

Evidence does not support the partisanship hypothesis for explaining Commission actions. Although the Commission rarely votes (Paterson; 2017: 352), it takes decisions by simple majority. Examination of Commission party majorities during the two terms under scrutiny do not provide evidence of any clear partisan pattern. In the 2010-2014 term (coinciding with Commission refusal to move beyond infringement procedures against the EPP-affiliated Hungarian government), the EPP did not dominate the Commission and in fact, the EPS and ALDE together (which supported the EP's resolutions critical of Hungary) had 14 Commissioners against the EPP's 13. In 20142019 (with initiatives concerning both Hungary and Poland) the EPP dominated by one (i.e. 14 to 13, with an additional one from CRE). In both Commissions the Presidents 
belonged to the EPP while the Commissioner in charge of the RoL portfolio belonged to the EPP in 2010-2014 (Reding) and the Socialisst and Democrats (S\&D) in 2014-2019 (Timmermans).

Evidence of internal Commission cohesion also questions the partisanship hypothesis. Neither socialist nor liberal Commissioners appear to have taken a more sanguine line than the one set by their EPP affiliated colleagues. During the Barroso (EPP) Commission, Reding (EPP) led action in the justice field, seconded by Rehn (European Alliance of Liberal and Democrats, ALDE), who cut financial assistance because the erosion of central bank's independence, and Kroes (ALDE), who acted against Hungarian media laws. During the Juncker Commission, Timmermans, Moedas (EPP) and Oettinger (EPP) joined Juncker (EPP) in loudly voicing their criticism of Orban's measures against the Central European University.

Commission meetings do not reveal any internal dissent. During the Juncker Commission, with a socialist (i.e. Timmermans) in charge, the College fully supported him in relation to Poland, with no dissenting vote or voice when he hinted at triggering Article 7 in December 2016 (Commission 2016), nor in December 2017 when it did. The only rupture of internal Commission cohesion emerged in relation to the Commission registration of an $\mathrm{ECl}$ on 24 November 2015 calling for the activation of a procedure against Hungary for breaches of the rule of law. The Commission took this decision in the absence of the Hungarian Commissioner Navracsics (Fidesz-EPP), who strongly objected. Juncker rebuked the complainant and reminded the Commissioner of his duty of neutrality, meaning that he could not represent his home country. ${ }^{. i}$

Evidence robustly supports the absence of causal value for partisanship. None of the people interviewed reported that partisanship had played any role in deciding 
Commission actions and several forcefully dismissed the suggestion that the different application of the RoL protection mechanisms to Hungary and Poland had anything to do with the partisan adscription of their respective governments. Former Commissioner Reding $(22,23,24)$ even argued that she resisted partisan pressures from the EP and the Council, while Timmermans (2017) declared that the Commission is politically colour blind when it comes to the RoL.

\subsection{Commission anticipation of unintended and unwanted consequences}

Anticipation of the effects/consequences of decisions as the basis for the explanation of Commission action/inaction informs three different hypotheses, about possible support in the Council, about the domestic effects of imposing some measure against the offending country and about the calculation of enforcement probabilities. Former DG Jonathan Faull clearly identified anticipation of consequences as a general frame for understanding Commission action:

when the Commission makes a proposal, [...] it has to think about how it will land on the other side of the road [...]. Will it work? And if it doesn't, what other consequences? Sometimes the Commission decides "I'm going to do it anyway. I believe it's right and this applies as much to fundamental rights as it does to banking regulation or product regulation". It can be anything but it's part of the consideration. How does it work in Parliament? How does it work in the 
Council? And if it doesn't, if it's rejected, what does it means for us, the

Commission? That is legitimate (Interview Faull 3:7)

The next three subsections explore the anticipation of effects of actions hypotheses.

\section{A. Calculation of support in the Council}

Evidence shows conclusively that the calculation of support in the Council/European Council played an essential role in the Commission's decision to trigger Article 7. Barroso had already warned in 2012 of the limitations of decision-making under Article 7 (Barroso; 2012) and Reding (2013) later repeated that unanimity rendered the article unusable. This in Reding's opinion justified finding an alternative Framework for the Commission to engage in political debate on its own initiative (Reding; 2014). The Commission justified its Framework, arguing that the thresholds for activating both mechanisms of Article 7 TEU are very high and underline the nature of these mechanisms as a last resort (Commission; 2014).

The interviewees overwhelmingly argue that the calculation of eventual support in the Council conditions absolutely any decision to activate Article 7. The general perception was that national governments were unwilling to become involved in RoL issues $(A ; 40)$. Lack of certainty of a positive outcome (upholding the Commission's recommendation) played a great role in Reding's perceptions $(2 ; 15)$ but did for Timmermans. The Commission feared several negative consequences if it did not obtain support, involving the risk of reinforcing offending governments $(F ; 9)$ and creating the impression of impunity (Reding 20; C; 21, 23) but the preservation of Commission's 
authority and prestige also played a salient role in the anticipation of effects (Reding; 21; C; 22, Almunia; 20). Reding (2013) summarised this later effect clearly: the worst result of a new RoL mechanism would be to leave the Commission institutionally damaged, and thus to eliminate the only institution currently generally accepted as being able to deal with a RoL crisis. In this sense, inaction serves to protect the Commission's institutional position.

Evidence of explicit national governments' positions shows scarce appetite for a more active role for the Commission in scrutinising domestic compliance with the RoL. Several governments expressed doubts on the Commission Framework, arguing that it unduly extended EU competence. The United Kingdom (UK) government argued that a new RoL mechanism was not needed and it opined that the RoL procedure undermined the role of Member States in the Council (UK Government; 2014). The Bulgarian Deputy Prime Minister voiced reluctance about the RoL Framework arguing that states reject external EU interference and ceding more sovereignty. ${ }^{\text {iii }}$ An opinion from the Council Legal Service echoed the same critical position on the perceived extension of the Commission's powers.

More assertively, several governments clearly expressed their refusal to support the Commission if it activated Article 7. The Hungarian government loudly voiced its opposition to any kind of sanctions against Poland and other governments, such as Slovakia's were also identified as potential allies for blocking any sanctions against Article 2 offenders (Oliver \& Stefanelli; 2016: 1081). Once the Commission launched its Framework against Poland, the position of governments did not turn more favourable to the Commission's ends. For instance, the UK government considered the matter the 
internal affairs of Poland. Juncker revealed his frustration, arguing that some states refuse to use Article 7 and this de facto cancels Article 7 a priori. ${ }^{\text {iv }}$

On this background, the Commission developed a central tool of its strategy: proactive action to build a majority in the Council. As former Commission Vice President Almunia noticed, it is unthinkable that this issue of Article 7 will be adopted without this previous preparation (Almunia 22, Hübner $18 \& 20$ ). Anticipating the negative effects mentioned above in the absence of Council support, Timmermans engineered a strategy for encouraging Council support. He invited the Council to debate Poland's breaches of the RoL and its government's defiant attitude. The Council meeting of 16 May 2017 decisively removed previous objections to Commission competence to activate the RoL Framework ( $C$ 17) but it also recorded broad support for its actions (F 5; Z 4). Timmermans (2017) recorded Member States support and used it to strengthen the Commission's stance against the Polish government.

After this Council meeting and in the face of the unwillingness of the Polish government to yield to the Commission's demands, several governments (such as Germany's and Slovenia's) started to voice their preparedness to support more assertive Commission action if needed. After a fresh signal of defiance from the Polish government in its response to the third Commission Recommendation under the RoL Framework, positive signals from governments gave the Commission cause to request the Council to discuss the Polish situation again in September 2017. The Council recorded the need for Poland and the Commission to engage in dialogue to find a solution (Timmermans; 2017). Both Council meetings implicitly upheld the Commission Framework, under which such dialogue should occur, dispelling previous reservations about its legality. More importantly, Macron and Merkel jointly pledged to back the 
Commission if it triggered Article 7 against Poland. ${ }^{v}$ This political backing created a suitable environment for triggering Article 7 (Hübner 5,6,15 and 21) and limited damage to the Commission should the procedure fail.

B. Unintended and undesired consequences (rally-round-the-flag effect) in the Commission's calculation

The theoretical construction of the hypothesis on rally around the flag looks at domestic popular mobilization. Certainly, interviewees coincide in identifying support in Polish public opinion for the EU and possible Commission actions in general [I, F], while they do not convey the same impression about Hungary with Reding (28), arguing that Orban had skilfully exploited infringement procedures to his own advantage. Certainly, the interviewees mention backfiring effects (Almunia; 6; Z; 7; F; 33; Faull 11; C; 30) but none of the people interviewed accorded any causal value to the risk of provoking a domestic mobilization in support of the government. Rather, Commission officials fear as backfiring effects the risk that a confrontation on the RoL could generally pollute a state's relations with the EU (A; 7 \&35). Thus, the kind of unintended and undesired consequences that play in Commission's calculations are the risk of creating and aloof and awkward partner. The Austrian precedent is mentioned in this sense (Timmermans; 2015b, Timmermans; 2016b;)

C. The compliance dilemma 
This hypothesis predicts that the Commission anticipates that engagement with national authorities rather than enforcement via article 7 secures better compliance. One interviewee indicated the limits to the Commission's enforcement capacities very bluntly: the Commission has limits to what it can do [...] And we cannot change a government, we cannot change Mr Orban (A, 33). Timmermans clearly stated that the only ones who could determine the fate of the Polish nation are the Polish people. We cannot do that, none of us (Timmermans; 2017) while another interviewee argued that to interfere at such a level in domestic affairs would be possible if the EU were a federal state [...] But we are not (F 13; also Tavares 11,17, 18).

These limits set the contours of Commission action modelled on two pillars. First, the Commission prefers to tackle any RoL issues as specific breaches of EU law and thus to treat them by means of infringement procedures. This preference emerged very strongly in the interviews. The interviewees portrayed these domestic breaches firstly and foremost in relation to EU competences. In these cases, they would then feel legitimised and emboldened to initiate Commission action via infringement procedures (Reding; 3,4,6; C 3,4,5, 6, 11, 15; A 1, 51; F 10; Z; 10,11; Almunia 1; Tavares 4,6,26). The Commission regards infringement procedures as creating the opportunity to engage with the offending state (rather as a merely sanctioning procedure). As several interviewees expressed, a preference for the infringement procedure derives from the fact that the Commission can administer the procedure and engage national governments. Thus, Commission preference for infringements associates with efficiency of the procedure: infringement is the most effective manner [...] we are not negotiating, 
we are asking the Member State to change and if they do not change we go to the Court of Justice (C 13).

The second pillar of the Commission strategy to tackle RoL breaches is precisely the preference for non-confrontational strategies based on engaging offending governments. The Commission has often expressed this preference. Thus, Barroso argued that the preservation of the RoL should be achieved by establishing dialogue with the Member State concerned to find solutions (Barroso; 2014). Reding argued that engaging and dialoguing was precisely the aim of the RoL mechanism, drawing inspiration from the way the Competition Law works. Because the sanctions only come after a long debate negotiation (Reding 12). Timmermans has also frequently endorsed the Commission's preference for dialogue with the aim of finding solutions without necessarily punishing (Timmermans; 2014) (Timmermans; 2015a; Timmermans; 2017): Our aim is to solve these issues; our aim is not to accuse, to go into a polemic. Our aim is to solve the issues in a rational way based on our legal obligations (Timmermans; 2016a).

The Commission has consistently explained the difference between Hungary and Poland in relation to the different disposition of the two governments to engage and dialogue. Timmermans justified differential treatment, referring precisely to the fact that the Hungarian authorities are prepared to talk to the Commission while the Polish ones are not: vi Poland and Hungary are different. Orbán and the Hungarian government have never refused a dialogue with us. A constructive dialogue (...) has stopped, for instance, decrease of the pension age for the judges. vii His judgement on the Polish case underlines the failures of the government to meet Commission's countless warnings, requests for dialogues and demands for clarification. Thus, he regretted that despite 
inviting the Polish to meet, $[\ldots]$ they rejected these invitations limiting exchanges to formal letters. [...] (Timmermans; 2017). Lacked of engagement opened the way to considering activating Article 7.

\section{Discussion}

The table below summarises the explanatory value that the findings grant to each hypothesis.

Table 2 above here

Evidence shows that the Commission anticipated the effects of its actions when deciding on the enforcement of RoL. The causal mechanism begins with the Commission's preference for compliance through instruments that can actively engage offending governments rather than those which could lead to severe sanctions (i.e. second stage of Article 7). This is because, apart from a genuine belief in its role as 'accompanying' national governments in seeking compliance, the Commission is well aware that lacking real coercion mechanisms, compliance depends on the will of national authorities. A preference for engagement mechanisms also explains why the Commission privileges infringement procedures instead of activating Article 7. The Commission seeks to identify breaches of specific law (treaty or secondary legislation) in cases related to the RoL, rather than to interpret them as a general violation of the values of Article 2. But even when the Commission activates infringement procedures in RoL cases, it prefers to 
administer enforcement politically, considering the Court stage and sanctions as the last resort.

In the absence of a legal basis to justify an infringement procedure, the Commission still prefers to pursue compliance by engaging in dialogue with the offending government. The RoL Framework in fact introduces this engagement mechanism into Article 7. Since engagement becomes a crucial compliance mechanism, the attitude of offending governments determines whether the Commission wants to advance to more severe enforcement mechanisms, i.e. activate Article 7. A lack of even symbolic commitment in the offending government to this engagement and dialogue strategy opens this option. However, enforcement does not follow automatically from the failure to engage if the Commission depends on another institution (i.e. the Council) to activate sanctioning mechanisms. The Commission anticipates both the support in the Council and the possible effects of any sanctioning action. Failing to obtain Council support can produce several very negative effects: implicit endorsement of the offending government, parallel disavowal of the Commission itself and consequently, the erosion of the enforcement procedure and the broader disengagement of the concerned state from the EU. Other effects, such as a possible negative domestic reaction (the rally-round-the-flag effect) do not appear to play an important role in Commission decisions on whether and how to act. Naturally, Commission's reluctance to activate article 7 because of the perception of lack of Council's support may be detrimental to the whole functioning and foundation of the EU legal order. A way of containing damage could be adopting more expedient decision-making procedures such as the reverse qualified majority that operates in the Excessive Deficit Procedure: the Council must adopt a Commission proposal unless governments reject it explicitly by 
qualified majority. Even if this change requires treaty reform, article 7 enforcement would be greatly strengthened.

7. Conclusion

The story behind Commission activation of Article 7 against the Polish government shows its preference for engagement strategies and its reluctance to use enforcement mechanisms. This story also shows the limits to the EU enforcement system: lacking last instance coercion, the Commission relies mainly on domestic cooperation and this can encourage governments to comply only symbolically or rhetorically (Bátory; 2016). Sanctions may play a role to obtain compliance in specific cases but its capacity to force systemic change remains untested. In any case, whether applying a more engaging or enforcing attitude, results seem fairly similar in both cases with a steady erosion of the separation of powers in favour of an increase of the powers of the executive. Whilst activation of article 7 against the Polish authorities shows some signs of engagement previously absent, whether it would suffice to reverse course remains questionable.

Carlos Closa is Professor at the Instituto de Políticas y Bienes Públicos (IPP), Spanish National Research Council (CSIC), Madrid, Spain and member of the faculty at the School of Transnational Governance (STG) at the EUI, Florence, Italy 
Calle Albasanz 26-28

Madrid 28037

\section{Carlos.closa@csic.es}

Acknowledgements:

This paper is part of the project Institutional design in comparative regional integration (InDeCRI) (CSO2016-76130-P) https://www.researchgate.net/project/InstitutionalDesign-in-Comparative-Regional-Integration-InDeCRI which is supported by a grant from the Spanish Research Agency. I presented a former version of this paper with the title The Commission and article 7. Explaining inaction...praising action? at EUSA, Miami 4-6 May 2017 and the ECPR General Conference, Oslo 6-9 September 2017. I thank Tanja Börzel, Johannes Pollack and the participants in both panels for their insightful comments and to Elin Helquist for her insights into sanctions literature and for her kind comments on an earlier draft. Two JEPP anonymous referees have also provided excellent feedback on the article. 
Endnotes

i The Commission officials are anonymized (and their names substituted by letters) while the former Commissioners are not, since their views are publicly known. Numbers refer to the order in the series of quotations extracted from the interview with this person.

ii Juncker rebukes Hungary's EU Commissioner 2 December 2015

https://euobserver.com/institutional/131353.

iii Adelina Marini EP pushes for strong Rule of Law Mechanism, Council and Commission are against 2 March 2015 http://www.euinside.eu/en/news/alde-want-a-democratic-governance-pact-butno-will-for-that

iv Kuczkiewicz, Jurek Juncker au «Soir»: «Il y a un sérieux problème de gouvernance en Europe» 5 novembre 2016 http://www.lesoir.be/1360084/article/actualite/union-europeenne/2016-1104/juncker-au-soir-il-y-un-serieux-probleme-gouvernance-en-europe

$\checkmark \quad$ Andrew Rettman Macron and Merkel take tough line on Poland EU Observer 15 December 2017 https://euobserver.com/justice/140320

vi Barigazzi, Jacopo and Quentin Ariès Commission's Orban plan: talk, threaten and seek allies 12 April 2017 http://www.politico.eu/article/commission-goes-with-stick-and-carrot-approach-to-hungaryviktor-orban/

vii Interview: Timmermans: 'Poland should be a leader in Europe - but it needs to cooperate' by Bartosz T. Wieliński, Gazeta Wyborcza http://www.euractiv.com/section/justice-homeaffairs/interview/timmermans-poland-should-be-a-leader-in-europe-but-it-needs-to-cooperate/

\section{Sources}

\section{Interviews}


- Almunia, J., Vice-president of the European Commission, Madrid 21 June 2017

- A., Adviser Juncker Cabinet, Brussels, 27 June 2017

- C., Head of Unit, Brussels 27 June 2017

- Faull, J., Director-General of Justice and Home Affairs from 2003 to 2010, Miami 4 May 2017

- F. , Deputy Director-General Brussels, 27 June 2017

- Hübner, D. Former Commissioner 2004-2009, Florence, 17 November 2017

- Oreja Aguirre, M., Former Commissioner (Member of the 1999 Three Wise Men Group), Madrid, 29 May 2017

- Reding, V., Former Commissioner Justice, Luxembourg, 26 June 2017

- Tavares, R., Former MEP, 2009-2014, Florence, 25 February 2018

- Z., Adviser Timmermans Cabinet, Brussels, 29 June 2017

Primary sources

- Barroso, J. M. Durão (2012) State of the Union address. Speech 12/596 http://europa.eu/rapid/press-release SPEECH-12-596 en.htm

- Barroso, J. M. Durão (2014) Remarks by President Barroso on the Future of Justice and Home Affairs and the Rule of Law Initiative (11 March 2014) http://europa.eu/rapid/press-release SPEECH-14-204 en.htm

- Commission (2014) A new EU Framework to strengthen the Rule of Law. Communication from the Commission to the European Parliament and the Council COM (2014) 158 final11 March 2014 
- Commission (2016) Minutes of the 2194th meeting of the Commission held in Brussels on Wednesday 21 December 2016 https://ec.europa.eu/transparency/regdoc/rep/10061/2016/EN/PV-20162194-F1-EN-MAIN-PART-1.PDF

- EP (2015a) Resolution of 10 June 2015 (2015/2700(RSP)) P8_TA(2015)0227 http://www.europarl.europa.eu/sides/getDoc.do?pubRef=-//EP//TEXT+TA+P8$\underline{\mathrm{TA}-2015-0227+0+\mathrm{DOC}+\mathrm{XML}+\mathrm{V} 0 / / \mathrm{EN}}$

- EP (2015b) Resolution of 16 December 2015 on the Situation in Hungary, (2015/2935(RSP)) P8_TA PROV(2015)0461

http://www.europarl.europa.eu/sides/getDoc.do?pubRef=-//EP//TEXT+TA+P8$\underline{\mathrm{TA}-2015-0461+0+\mathrm{DOC}+\mathrm{XML}+\mathrm{V} 0 / / \mathrm{EN}}$

- EP (2017a) Resolution of 17 May 2017 on the situation in Hungary, P8_TA$\operatorname{PROV}(2017) 0216$

- http://www.europarl.europa.eu/sides/getDoc.do?pubRef=-//EP//TEXT+TA+P8TA-2017-0216+0+DOC+XML+V0//EN\&language $=E N$

- EP (207b) Resolution of 15 November 2017 on the situation of the rule of law and democracy in Poland (2017/2931(RSP)) P8_TA-PROV(2017)0442

- Reding, V. (2013) The EU and the Rule of Law - What next? Speech at the Centre for European Policy Studies/Brussels 4, September 2013, SPEECH/13/677 http://europa.eu/rapid/press-release SPEECH-13-677 de.htm

- Reding, V. (2014) A new EU Framework to safeguard the rule of law in the European Union Presentation at the General Affairs Council 18 March 2014 SPEECH/14/228 https://archive.org/stream/SPEECH14228EN/SPEECH-14$\underline{228 \text { EN djvu.txt }}$ 
- Timmermans; F. (2014) Answers to the European Parliament Questionnaire to the Commissioner-Designate https://ec.europa.eu/commission/sites/cwt/files/commissioner ep hearings/2 014-ep-hearings-reply-timmermans en.pdf

- Timmermans, F. (2015a) Speech to the European Parliament EU Framework for Democracy, Rule of Law and Fundamental Rights' 12 February 2015 Speech/15/4402 http://europa.eu/rapid/press-release SPEECH-154402 en.htm

- Timmermans, F. (2015b) The European Union and the Rule of Law - Keynote speech at Conference on the Rule of Law, Tilburg University, 31 August 2015 https://ec.europa.eu/commission/commissioners/20142019/timmermans/announcements/european-union-and-rule-law-keynotespeech-conference-rule-law-tilburg-university-31-august-2015 en

- Timmermans, F. (2016a) Readout of the College Meeting of 13 January 2016 http://europa.eu/rapid/press-release SPEECH-16-71 en.htm?locale=en

- Timmermans; F. (2016b) Statement by First Vice-President Frans Timmermans and Commissioner Günther Oettinger - EP Plenary Session - Situation in Poland, Strasbourg, 19 January 2016.

- Timmermans, F. (2017) Opening and closing remarks of First Vice-President Frans Timmermans on the Rule of Law in Poland, at the European Parliament's Committee on Civil Liberties, Justice and Home Affairs SPEECH/17/3042 http://europa.eu/rapid/press-release SPEECH-17-3042 en.htm

- UK Government (2014) Review of the balance of Competences between the UK and the EU-EU enlargement 
References

- Ahtisaari, M.; J. Frowein and M. Oreja, (2000) Report (8 September) http://www2.ohchr.org/english/bodies/hrc/docs/ngos/HOSI-1.pdf.

- Allen, S. (2008) 'The Domestic Political Costs of Economic Sanctions' The Journal of Conflict Resolution, Vol. 52, No. 6, 916-944.

- Batory, A. (2016) 'Defying the Commission: creative compliance and respect for the Rule of Law in the EU' Public Administration Vol. 94, No. 3, 685-699.

- Bieber, R. and F. Maiani (2014) 'Enhancing Centralised Enforcement of EU Law: Pandora's Toolbox?' 51 Common Market Law Review 1057-1092.

- Blauberger, M. and D.R. Kelemen (2017) 'Can courts rescue national democracy? Judicial safeguards against democratic backsliding in the EU', Journal of European Public Policy, 24:3, 321-336, DOI:

$10.1080 / 13501763.2016 .1229357$

- Börzel, T. A. (2001) 'Non-Compliance in the European Union: Pathology or Statistical Artefact?' Journal of European Public Policy 8: 803-24.

- Börzel, T. A., T. Hofmann, D. Panke, and C. Sprungk (2010) 'Obstinate and Inefficient: Why Member States Do Not Comply with European Law' Comparative Political Studies 43: 1363-90.

- Checkel, J. T. (2001) 'Why Comply? Social Learning and European Identity Change' International Organization 55: 553-88. 
- Conant, L. (2012) 'Compliance and What EU Member States Make of It', in M. Cremona (ed.) Compliance and the Enforcement of EU Law. Oxford: Oxford University Press, 1-29.

- Editors CMLR (2016) 'Editorial Comments, The Rule of Law in the Union, the Rule of Union Law and the Rule of Law by the Union: Three Interrelated Problems', 53 Common Market Law Review 597-605.

- Egeberg, M. (2014) 'The European Commission: from agent to political institution' Public Administration 92: 1 240-246.

- Falkner, G. (2013) 'The JCMS Annual Review Lecture: Is the European Union Losing its Credibility?', Journal of Common Market Studies, 51, S1, 13-30.

- Galtung, Johan (1967) 'On the Effects of International Economic Sanctions: With Examples from the Case of Rhodesia' World Politics, 19:3, 378-416.

- Grabbe, H. (2014) 'Six Lessons of Enlargement Ten Years On: The EU's Transformative Power in Retrospect and Prospect' Journal of Common Market Studies 52 Annual Review 40-56.

- Grauvogel, J. and von Soest, C. (2014) 'Claims to legitimacy count: Why sanctions fail to instigate democratisation in authoritarian regimes' European Journal Political Research, 53: 635-653. doi:10.1111/1475-6765.12065.

- Hartlapp, M. (2007) ‘On Enforcement, Management and Persuasion: Different Logics of Implementation Policy in the EU and the ILO', Journal of Common Market Studies, 45, 3, 653-74. 
- Kassim, H.; J. Peterson, M. W. Bauer, S. Connolly, R.Dehousse, L. Hooghe, A. Thompson (2013) The European Commission of the Twenty-First Century (Oxford: OUP).

- Kelemen, D. R. (2017) 'Europe's Other Democratic Deficit: National Authoritarianism in Europe's Democratic Union' Government and Opposition 52: $2211-238$.

- Kochenov, D. (2016) 'The Commission vs Poland: The Sovereign State Is Winning 1-0', VerfBlog, 2016/1/25, http://verfassungsblog.de/the-commission-vspoland-the-sovereign-state-is-winning-1-0 DOI: https://dx.doi.org/10.17176/20160126-172908.

- Kochenov, D.and L. Pech (2016) 'Better Late than Never? On the European Commission's Rule of Law Framework and its First Activation' Journal of Common Market Studies 54: 5 1062-1074.

- Lindsay, J. M. (1986) 'Trade Sanctions as Policy Instruments: A re-examination' International Studies Quarterly 30, 153-173.

- Mendrinou, M. 1996. 'Non-Compliance and the European Commission's Role in Integration', Journal of European Public Policy, 3: 1, 1-22.

- Merlingen, M., Mudde, C. and Sedelmeier, U. (2001) 'The right and the righteous? European norms, domestic politics and the sanctions against Austria', Journal of Common Market Studies 39(1): 59-77.

- Nugent, N. and M. Rhinard (2016) Is the European Commission Really in Decline? Journal of Common Market Studies 54: 1199-1215. doi: $\underline{10.1111 / j \mathrm{jcms} .12358}$. 
- Oreja, M. (2011) Memoria y esperanza. Relatos de una vida (Madrid: la Esfera de los Libros).

- Pape, R. A. (1997) 'Why economic sanctions do not work' International Security 22: 2 90-136.

- Pech, L.; Scheppele, K. L. (2017a) 'Poland and the European Commission, Part I: A Dialogue of the Deaf?', VerfBlog, 2017/1/03, http://verfassungsblog.de/poland-and-the-european-commission-part-i-adialogue-of-the-deaf/.

- Pech, L.; Scheppele, K. L. (2017b) 'Illiberalism Within: Rule of Law Backsliding in the EU Cambridge' Yearbook of European Legal Studies 19, 3-47. doi:10.1017/cel.2017.9.

- Peterson, J. (2017) 'Juncker's political European Commission and an EU in crisis' Journal of Common Market Studies 55: 2 349-367 DOI: 10.1111/jcms.12435.

- Oliver, P. and J. Stefanelli (2016) 'Strengthening the Rule of Law in the EU: The Council's Inaction' Journal of Common Market Studies 54: 5 1075-1084.

- Rawlings, R. 2000. 'Engaged Elites: CitizenAction and Institutional Attitudes in Commission Enforcement' European Law Journal, 6:1, 4-28.

- Sadecki A. (2014) 'In a State of Necessity: How has Orban changed Hungary?' Centre for Eastern Studies. Available at:

http://www.osw.waw.pl/sites/default/files/pw 41 in-a-stateofnecessity net.pdf.

- Sargentini, J. and A. Dimitrovs (2016) 'The European Parliament's Role: Towards New Copenhagen Criteria for Existing Member States?' Journal of Common Market Studies 54. 5 1085-1092. 
- Sedelmeier, U. (2014), 'Anchoring Democracy from Above? The European Union and Democratic Backsliding in Hungary and Romania After Accession', Journal of Common Market Studies, 52.1: 105-121.

- Sedelmeier, U. (2017) Party-politics as Usual? Positions of the European Parliament's Political Groups towards Sanctions against Democratic Backsliding Paper presented at the Fifteenth Biennial Conference of the European Union Studies Association, 4-6 May 2017, Miami Florida.

- Scheppele, K.L. (2016) 'EU Can Still Block Hungary's Veto on Polish Sanctions', 11 January 2016, Politico.eu. http://www.politico.eu/article/eu-can-still-blockhungarys-orban-veto-onpolish-pis-sanctions/.

- Schlipphak, B. \& O. Treib 'Playing the blame game on Brussels: the domestic political effects of EU interventions against democratic backsliding' Journal of European Public Policy, 24:3,352-365, DOI: 10.1080/13501763.2016.1229359.

- Tallberg, J. 2002. 'Paths to Compliance: Enforcement, Management, and the European Union', International Organization, 56.3:609-43.

- Tansey, O. (2017) 'Process Tracing and Elite Interviewing: A Case for Nonprobability Sampling' PS: Political Science and Politics, 40(4), 765-772. doi:10.1017/S1049096507071211 40.4.

- Van Hüllen, V. and Börzel, T.A. (2013) 'The EU's Governance Transfer. From External Promotion to Internal Protection?' SFB-Governance Working Paper No 56.

- Varnagy, R. (2013) 'Hungary', European Journal of Political Research (Political Data Yearbook) 52:96-100. 
- Vitorino, A. (2012) 'Preface', in P. Ponzano, C. Hermanin and D. Corona The Power of Initiative of the European Commission: A Progressive Erosion? Notre Europe Study and Research 89 http://www.notreeurope.eu/media/commission power of initiative ne feb2012.pdf?pdf=ok.

- Wille, A. (2013) The Normalization of the European Commission: Politics and Bureaucracy in the EU Executive (Oxford: Oxford University Press).

- Wilms, G. (2017) Protecting Fundamental Values in the European Union through The Rule of Law Articles 2 and 7 TEU from a legal, historical and comparative angle Florence: RSCAS, doi:10.2870/083300 http://cadmus.eui.eu/handle/1814/44987.

- Wonka, A. (2008) 'Decision-making dynamics in the European Commission: partisan, national or sectoral?' Journal of European Public Policy 15.8: 11451163.

- Zalan, E. (2015), 'EP to Hold Debate on Kaczynski's Poland', EU Observer, 8 December, https://euobserver.com/political/131438. 